\title{
BATASAN WAKTU PERKAWINAN DALAM \\ PERKARA ISBAT NIKAH PADA SIDANG KELILING \\ DI PENGADILAN AGAMA CIANJUR
}

\author{
Fahmi Muwahid, Riyan Ramdhani \\ Fakultas Syari'ah dan Hukum, UIN Sunan Gunung Djati Bandung \\ E-mail :fahmimuwahid97@gmail.com
}

\begin{abstract}
Isbat nikah is one of the products of the Religious Court in the form of the determination of the marriage of a husband and wife that has been carried out in accordance with Islamic provisions. However, in the Cianjur Religious Court there are special rules regarding circuit courts in marital isbat cases, namely the year of marriage for the maximum marriage isbat in 2010, above 2010 must be registered at the Cianjur Religious Court office. This study departs from a rule that has been enacted but there are no additional rules regarding the time limit of marriage in marriage isbat cases in a circuit court. As stated in Perma No 1 of 2015 which only regulates the mechanism of the implementation of an integrated isbat trial. While the rule of law remains based on existing rules. It is stated in Article 11 paragraph (9) which states: The hearing in the Integrated Service is conducted in accordance with the procedural law and the applicable provisions. By using the descriptive analysis method, the research is first, the background of the marital time limit in marriage isbat cases which are settled in a circuit court in the Cianjur Religious Court. Second, the process of conducting a trial around isbat nikah with a time limit in the Cianjur Religious Court is no different from the process of conducting a trial around a isbat nikah case. The three rules made by the chairman of the Religious Court do not contradict the rules that already exist in the Compilation of Islamic Law (KHI) or in the request No. 1 of 2015 concerning Integrated Service Mechanisms.
\end{abstract}

Keywords: Isbat nikah, Traveling Session, Rules of the Chairperson of the Cianjur Religious Court.

\begin{abstract}
Abstrak
Isbat nikah merupakan salah satu produk Pengadilan Agama dalam bentuk penetapan atas perkawinan seorang suami dan istri yang sudah dilaksanakan sesuai dengan ketentuan Islam. Namun, di pengadilan Agama Cianjur terdapat aturan khusus mengenai sidang keliling dalam perkara isbat nikah, yaitu Tahun menikah untuk isbat nikah maksimal tahun 2010, di atas tahun 2010 harus daftar ke kantor Pengadilan Agama Cianjur. Penelitian ini bertolak dari sebuah aturan yang sudah diberlakukan tetapi belum ada aturan tambahan perihal batasan waktu perkawinan dalam perkara isbat nikah pada sidang keliling. Seperti yang tercantum dalam Perma No 1 Tahun 2015 yang hanya mengatur mekanisme pelaksanaan sidang isbat terpadu. Sementara untuk aturan hukum tetap berdasar kepada aturan yang telah ada. Tertuang dalam Pasal 11 ayat (9) yang menyatakan: Pelaksanaan sidang dalam Pelayanan Terpadu dilakukan sesuai dengan hukum acara dan ketentuan yang berlaku. Dengan menggunakan metodel deskriptif analisis menghasilkan penelitian yakni pertama, Latar belakang batasan waktu perkawinan dalam perkara isbat nikah yang diselesaikan dalam sidang
\end{abstract}


keliling di pengadilan Agama Cianjur. Kedua, proses pelaksanaan sidang keliling isbat nikah dengan batasan waktu di Pengadilan Agama Cianjur tidak berbeda dengan proses pelaksanaan sidang keliling perkara isbat nikah. Ketiga aturan yang di buat oleh ketua Pengadilan Agama itu tidak bertentangan dengan aturan yang sudah ada dalam Kompilasi Hukum Islam (KHI) ataupun dalam perma No 1 Tahun 2015 Tentang Mekanisme Pelayanan Terpadu.

Kata Kunci: Isbat Nikah, Sidang Keliling, Aturan Ketua Pengadilan Agama Cianjur.

\section{PENDAHULUAN}

Sidang keliling adalah Sidang diluar gedung peradilan yang dilaksanakan secara tetap, berkala atau sewaktu-waktu oleh Pengadilan disuatu tempat yang ada di wilayah hukumnya tetapi diluar tempat kedudukan gedung Pengadilan dalam bentuk sidang Keliling atau sidang di tempat sidang tetap. ${ }^{1}$ Jenis perkara yang ditangani dalam sidang keliling hanyalah perkara yang bersifat "ringan". Adapun yang dimaksud dengan jenis perkara ringan dalam sidang keliling yaiu tertera dalam PERMA Nomor 1 Tahun 2014 pasal 16 adalah perkara yang mudah untuk dilakukan pembuktiannya. Artinya perkara ringan yang dimaksud bisa diselesaikan dalam sidang keliling bukan hanya tentang perkara voluntair melainkan perkara contentius juga bisa, hal tersebut tergantung pengklasifikasian dari beda perkara tersebut. Adapun jenis perkara yang dapat dilakukan pada sidang keliling diantaranya adalah isbat nikah, cerai gugat, cerai talak, pengggabungan perkara isbat dan cerai gugat/cerai talak apabila pernikahan tidak ada bukti dan mengajukan perceraian, hak asuh anak dan penetapan ahli waris.

Norma hukum lain yang juga mengatur mengenai sidang keliling adalah Keputusan Ketua Muda Urusan Lingkungan Peradilan Agama dan Sekretaris Mahkamah Agung RI Nomor 04/TUADAAG/II/2011 dan Nomor 020/SEK/SK/II/2011 Tentang Petunjuk Pelaksanaan Surat Edaran Mahkamah Agung RI. Nomor 10 Tahun 2010 Tentang Pedoman Bantuan Hukum Lampiran B dan Keputusan Ketua Mahkamah Agung RI No. 026/KMA/SK/II/2012 tentang Standar Pelayanan Peradilan pada Bab IV huruf G. Kemudian pada tanggal 07 Januari 2013, ditetapkan Buku Pedoman Pelaksanaan Sidang Keliling (BUPEDLAKSILING) melalui Surat Keputusan Ketua Muda Mahkamah Agung RI Urusan Lingkungan Pengadilan Agama No. 01/SK/TUADAAG/I/2013 tentang Pedoman Sidang Keliling di Lingkungan Peradilan Agama.

Sidang keliling, atau sidang di luar gedung Pengadilan, merupakan salah satu penjabaran dari acces to justice, yang telah menjadi komitmen masyarakat hukum di banyak negara. Sidang keliling ini merupakan langkah untuk mendekatkan "pelayanan hukum dan keadilan" kepada masyarakat. Sebagai program pengembangan dari asas

${ }^{1}$ Perma No. 1 Tahun 2014 Pedoman Pemberian Layanan Hukum Bagi Masyarakat Tidak Mampu di Pengadilan.

28 Jurnal Al-Ahwal Al-Syakhsiyyah : Jurnal Hukum Keluarga dan Peradilan Islam 
acces to justice, sidang keliling mesti mendapat perhatian dari semua pihak yang terkait, sehingga keadilan dapat terjangkau oleh setiap orang (justice for all). ${ }^{2}$ Sidang keliling juga merupakan salah satu dari bentuk nyata dari sebuah kebijakan publik. Menurut Edi Suharto dalam buku analisis kebijakan publik menyatakan bahwa kebijakan publik merupakan prinsip atau cara bertindak yang dipilih untuk mengarahkan pengambilan keputusan. ${ }^{3}$ Pengadilan Agama Cianjur mengeluarkan kebijakan bahwa yang ditangani dalam sidang keliling adalah perkara isbat nikah. Sidang keliling dengan perkara perkara isbat nikah dikarenakan banyak masyarakat yang telah melaksanakan perkawinan yang tidak memiliki akta nikah, dikarenakan perkawinan yang tidak tercatat di Kantor Urusan Agama. Perkara Isbat Nikah merupakan perkara yang banyak terjadi pada masyarakat di daerah Cianjur. Banyak perkawinan yang dilaksanakan di wilayah kecamatan Cidaun Kabupaten Cianjur tetapi tidak didaftarkan ke Kantor Urusan Agama Cidaun Kabupaten Cianjur sebagai legitimasi bukti pekawinan yang sah menurut Negara. ${ }^{4}$ Beberapa faktor yang menjadi alasan warga kecamatan Cidaun Kabupaten Cianjur tidak mau mendaftarkan nikah ke Kantor Urusan Agama Cidaun Kabupaten Cianjur, diantaranya karena: Biaya, Jarak yang cukup jauh, dan budaya yang dipegang oleh masyarakat itu sendiri. Juga masih banyak beranggapan perkawinan diluar Kantor Urusan Agama itu masih bisa di laksanakan Isbat Nikah yang dilakukan di Pengadilan Agama.

Berangkat dari banyaknya anggapan masyarakat di wilayah Cianjur atas pernikahan yang dilaksanakan diluar Kantor Urusan Agama dapat diselesaikan dengan Isbat Nikah melalui sidang keliling, maka ketua Pengadilan Agama Cianjur mengeluarkan aturan khusus yang tidak secara tertulis tentang batasan usia pernikahan yang dapat melaksanakan Isbat Nikah melalui sidang keliling. Sebagaimana kutipan hasil wawancara peneliti dengan panitera Pengadilan Agama Cianjur, bahwa aturan yang dikeluarkan oleh ketua Pengadilan Agama Cianjur tersebut kurang lebih redaksinya sebagai berikut: "Tahun menikah untuk isbat nikah maksimal tahun 2010, yang di atas tahun 2010 harus daftar ke kantor Pengadilan Agama Cianjur"

Aturan khusus yang dikeluarkan oleh ketua Pengadilan Agama Cianjur apabila di tinjau berdasarkan prinsip penegakan hukum maka akan bertentangan. Karena dalam penegakan hukum memiliki prinsip keadilan merupakan keinginan semua yang berperkara dalam seluruh lapisan masyarakat, tanpa melihat adanya pengklasifikasian. Perwujudan demi tercapainya keadilan bisa dicapai manakala semua unsur dapat melaksanakan kewajibannya sesuai dengan fungsinya masing- masing. Antara peraturan perundang-undangan, pelaksanaan dan pengguna dapat berperan sebagai-

2 SK Ketua Muda MA RI Urusan Lingkungan Pengadilan Agama No. 01/SK/TUADAAG/I/2013 tentang Pedoman Sidang Keliling di Lingkungan Peradilan Agama, h. 3

${ }^{3}$ Edi Suharto, Analisis Kebijakan Publik, Bandung: Alfabeta, 2005, hal 7

${ }^{4}$ UU NO 1 Thn 1974 UU Perkawinan

Jurnal Al-Ahwal Al-Syakhsiyyah : Jurnal Hukum Keluarga dan Peradilan Islam 29 
mana fungsinya.

Berdasarkan hal tersebut diatas, peneliti merasa perlu unutk meneliti lebih dalam lagi tentang aturan khusus dalam perkara Isbat Nikah pada sidang keliling yang dilaksanakan oleh Pengadilan Agama Cianjur yang berjudul "Batasan Waktu Perkawinan dalam Perkara Isbat Nikah pada Sidang Keliling di Pengadilan Agama Cianjur". Adapun secara sistematis tujuan yang ingin dicapai dalam penelitian ini adalah Pertama, Untuk mengetahui latar belakang batasan waktu perkawinan dalam perkara isbat nikah pada sidang keliling di Pengadilan Agama Cianjur, kedua Untuk mengetahui pelaksanaan batasan waktu perkawinan dalam perkara isbat nikah pada sidang keliling di Pengadilan Agama Cianjur, dan ketiga Untuk Mengetahui tinjauan yuridis terhadap batasan waktu perkawinan dalam perkara isbat nikah pada sidang keliling di Pengadilan Agama Cianjur.

\section{METODOLOGI}

Metode yang dilakukan dalam penyusunan skripsi ini adalah metode deskriptif analisis. Alasan kenapa metode deskriptif Analisis ini diambil adalah karena data yang diambil merupakan kejadian yang sudah terjadi atau peristiwa yang hanya bisa di teliti melalui pendeskripsian kejadian atau peristiwa tersebut. Menurut Nazir bahwa metode deskriptif analisis adalah suatu metode dalam meneliti status sekelompok manusia, suatu objek, suatu set kondisi, suatu sistem pemikiran, ataupun suatu kelas peristiwa pada masa sekarang. ${ }^{5}$ Dalam hal ini penulis menitik beratkan pada penelitian sidang keliling Pengadilan Agama Cianjur yang menangani perkara isbat nikah di Kabupaten Cianjur.

Dalam penelitian ini, penulis menentukan tempat penelitian yaitu di wilayah Pengadilan Agama Cianjur Berdasarkan pengamatan yang dilakukan pada observasi terlihat bahwa sidang keliling yang dilakukan oleh Pengadilan Agama Cianjur yang menangani perkara isbat nikah sangat unik dan berimplikasi pada kepercayaan waraga masyarakat terhadap sebuah kepastian hukum. Sumber Data dalam penelitian ini diperoleh dengan sumber data primer menetapkan informan yaitu ketua Pengadilan Agama, Panitera dan hakim yang bertugas menyidangkan isbat nikah. Dan sumber datasekunder yaitu berupa buku dan bahan yang berhubungan dengan masalah penelitian. Adapun teknik pengumpulan data yang digunakan antara lain Wawancara, dan Studi kepustakaan yaitu pegumpulan data yang dilakukan penulis dalam penelitian ini dalam berbagai literature (Buku-buku) yang berkaitan dengan masalah yang di bahas.

${ }^{5}$ Nazir.. Metode Penelitian, Ceatakan kedelapan, Bogor: Ghalia Indonesia. 2013. Hlm. 43

30 Jurnal Al-Ahwal Al-Syakhsiyyah : Jurnal Hukum Keluarga dan Peradilan Islam 


\section{PEMBAHASAN DAN HASIL PENELITIAN}

Kata isbat memiliki arti penetapan, penyungguhan atau pe-nentuan. Mengisbatkan artinya menyungguhkan, menentukan atau menetapkan (kebenaran sesuatu). ${ }^{6}$ Menurut pendapat Abu Thalib selaku Hakim di Pengadilan Agama Pekanbaru, beliau menyatakan isbat nikah yaitu sebuah pernikahan antara suami istri tetapi belum ditetapkan sahnya oleh Kantor Urusan Agama (KUA), dengan kata lain menetapkan nikah yang sudah memenuhi rukun dan syarat perkawinan tetapi belum disahkan secara administrasi, maka sekarang disahkan secara administrasi dalam mengajukan isbat nikah ke Pengadilan Agama.

Nikah secara bahasa berarti bersenggama atau bercampur, Para ulama ahli fiqh berbeda pendapat tentang makna nikah, namun secara keselurahan dapat dipahami bahwa nikah menurut ahli fiqh berarti akad nikah yang ditetapkan oleh syara. Maka dengan demikian seorang suami dapat memanfaatkan dan bersenang- senang dengan kehormatan seorang istri serta seluruh tubuhnya. ${ }^{7}$

Isbat nikah adalah penetapan atas perkawinan seorang pria dengan seorang wanita sebagai suami istri yang sudah dilaksanakan sesuai dengan ketentuan agama Islam yaitu sudah terpenuhinya syarat dan rukun nikah, tetapi pernikahan tersebut belum atau tidak dicatatkan kepejabat yang berwenang, dalam hal ini adalah pejabat Kantor Urusan Agama (KUA) yaitu Pegawai Pencatat Nikah (PPN).

Isbat nikah merupakan produk Pengadilan Agama dalam bentuk penetapan artinya bukan pengadilan yang sesungguhnya dan di istilahkan dengan jurisdikti ovoluntair. Dikatakan bukan pengadilan yang sesungguhnya, karena dalam perkara ini hanya ada pemohon, yang memohon untuk ditetapkan tentang sesuatu yaitu penetapan nikah. Perkara voluntair adalah perkara yang sifatnya permohonan dan didalamnya tidak terdapat sangketa, sehingga tidak ada lawan. Pada dasarnya perkara permohonan tidak dapat diterima, kecuali kepentingan undang-undang menghendaki demikian. ${ }^{8}$

Perkara volunteir yang dapat diajukan ke Pengadilan Agama seperti: 1. Penetapan wali pengampu bagi ahli waris yang tidak mampu untuk melakukan tindakan hukum; 2. Penetapan pengangkatan wali; 3. Penetapan pengangkatan anak; 4. Penetapan nikah (isbat nikah); 5. Penetapan wali adhol. Karena penetapan itu muncul sebagai produk pengadilan atas permohonan-permohonan yang tidak berlawan maka dalam putusan penetapan tidak akan berbunyi menghukum melainkan bersifat menyatakan (declatoir).

Beberapa faktor yang menjadi alasan warga kecamatan Cidaun Kabupaten

6 Tim Penyusun Kamus, Kamus Besar Bahasa Indonesia, (Jakarta : Balai Pustaka, 1990), Cet. Ke-3, hlm. 339.

${ }^{7}$ Djamaan Nur, Fiqh munakahat, (Semarang:Toha Putra, 1993) hlm.1

8 Mukti Arto, Praktek Perkara Perdata Pada Pengadilan Agama, (Yogyakarta : Pustaka Pelajar, 1996, hlm. 41

Jurnal Al-Ahwal Al-Syakhsiyyah : Jurnal Hukum Keluarga dan Peradilan Islam 31 
Cianjur tidak mau mendaftarkan nikah ke Kantor Urusan Agama Cidaun Kabupaten Cianjur, diantaranya karena: Biaya, Jarak yang cukup jauh, dan budaya yang dipegang oleh masyarakat itu sendiri. Juga masih banyak beranggapan perkawinan diluar Kantor Urusan Agama itu masih bisa di laksanakan Isbat Nikah yang dilakukan di Pengadilan Agama. Sehingga Pengadilan Agama Cianjur mengeluarkan aturan khusus yang tidak secara tertulis tentang batasan usia pernikahan yang dapat melaksanakan Isbat Nikah melalui sidang keliling. Sebagaimana kutipan hasil wawancara peneliti dengan panitera Pengadilan Agama Cianjur, bahwa aturan yang dikeluarkan oleh ketua Pengadilan Agama Cianjur tersebut kurang lebih redaksinya sebagai berikut:

"Tahun menikah untuk isbat nikah maksimal tahun 2010, yang di atas tahun 2010 harus daftar ke kantor Pengadilan Agama Cianjur"

\section{Adanya Batasan Waktu Perkawinan dalam Perkara Isbat Nikah yang Diselesaikan dalam Sidang Keliling di Pengadilan Agama Cianjur.}

Faktor yang Melatarbelakangi

Pertama, ditemukan fakta bahwasanya di Desa Cidamar Kecamata Cidaun Kabupaten Cianjur banyak masyarakat yang tidak tercatat pernikahan di Kantor Urusan Agama (KUA) Kecamatan Cidaun, pada tahun 2010 ke bawah banyak tidak tercatat sedangkan masyarakat yang menikah 2010 ke atas jumlahnya tidak terlalu banyak dibandingkan dengan masyarakat yang menikah pada tahun 2010 ke bawah. Maka berdasarkan hal tersebut Pengadilan Agama Cianjur melalui kebijakan ketua Pengadilan Agama mengeluarkan aturan yang berbunyi. "Bagi pernikahan yang di lakukan di atas tahun 2010 sidang perkara Isbat Nikah dilaksanakan di kantor Pengadilan Agama Cianjur, adapun yang di bawah batasan pernikahan tahun 2010 sidang perkara Isbat Nikah di laksanakan di tempat sidang keliling." 9

Kedua, Pemohon yang mengajukan isbat Nikah yang melaksanakan pernikahana pada tajun 2010 dapat dikatakan kondisi fisiknya sudah tidak lagi prima, maka apabila mereka melaksanakan persidangan di Gedung Pengadilan Agama, hal tersebut membuat masyarakat yang mau mengajukan perkara isbat nikah enggan melaksanakan tersebut maka ketua Pegadilan Agama mengeluarka kebijakan, sesuai dengan hasil wawancara dengan bapak Asep selaku hakim yang terlibat dalam pembuatan aturan tersebut, berikut kutipannya. "Maka dari banyaknya itu ketimbang mereka yang berangkat ke gedung pengadilan agama dan ratusan yang datang ke pengadilan lebih baik kita tiga orang yang datang kesana itu lah yang di sebut sidang keliling, jadi kenapa kita datang kesana melihat dari sisi sosiologis dan sisi fisikologis (Fisik) mereka, yang

9 Wawancara dengan bapak Asep selaku salah satu hakim yang terlibat dalam perumusan aturan pembatasan isbat nikah pada sidang keliling 22 April 2019.

32 Jurnal Al-Ahwal Al-Syakhsiyyah : Jurnal Hukum Keluarga dan Peradilan Islam 
pertama jumlahnya banyak, fisiknya lemah, jaraknya jauh memakan biaya yang mahal dan rata rata mereka datang dari desa, maka pentinglah kita datang ke mereka. Sementara yang 2010 ke sini umumnya bisa kebayanglah muda-muda, sudah mengenal kota, keadaanya mungkin karena moralitas jumlahnya sedikit, ya lebih baik datang ke sini kesiapan kantor juga kalau hanya, lima atau sepuluh perkara yang dating bisa ditangani kalau yang datang ratusan perkara disininya kurang kondusif, jadi melihat dari sisi efisiensinya, efisiensi pelayanan, kesempatan efisiensi kantor pelayanan.

Maka, substansi dari pelayanan sidang keliling itu adalah menolong kita mengarah kesana, itu dalam rangka pelayanan prima, pelayanan kepada masyarakat, makanya umumnya di desa-desa yang mengajukan isbat nikah adalah tua tua, yang sudah memiliki anak enam, dan anaknya juga sudah pada menikah, dan anak yang sudah menikah sudah mempunyai akta nikah, makanya mereka sering disentil pertanyaan hakim "Bapak kenapa pas dulu nikah tidak ada akta nikah" jawaban pemohon "anak-anak mah kan sudah pada pinter, kalau bapak dulu tidak tahu". Bagi mereka nikah itu kesan bagi nikah siri itu tidak bergengsi, tapi kalau nikah melalui di catat, di rayakan juga prosesi, apalagi sekarang kalau di kota dilakukannya di gedung, di rumah makan di situ kehormatannya, coba kalau pernikahan langsung makanmakan tidak ada kehormatanya, itu sudah menjadi trend anak muda, juga memang harus banyak yang tahu." 10

Ketiga, adanya pemahaman masyarakat nikah membudaya itu di karenakan dengan nikah agama juga sudah sah, maka sekarang menjadi tantangan buat petugas Pengadilan Agama untuk sosialisasi lebih lanjut, sesuai dengan hasil wawancara dengan bapak Asep selaku hakim di Pengadilan Agama Cianjur, berikut kutipannya. “juga jangan sampai gagal paham maksud gagal faham yaudah lah pernikahan agama aja we dulu gampang nanti di isbatkan saja di pengadila agama, karena melihat realitas murah, kalau melihat pembicaraan tadi bukan semakin berkurang tetapi semakin bertambah, disitulah perlunya sosialisasi hukum perihal UU No 1 Tahun 1974." 11

Keempat, Kesadaran hukum mempunyai beberapa konsepsi, salah satunya konsepsi mengenai kebudayaan hukum. Konsepsi ini mengandung ajaran-ajaran kesadaran hukum lebih banyak mempermasalahkan kesadaran hukum yang dianggap sebagai mediator antara hukum dengan perilaku manusia, baik secara individual maupun kolektif. ${ }^{12}$ Berdasarkan hal tersebut ketua pengadilan Agama mengeluarkan kebijakan untuk meminimalisir tersebut sebagai payung hukum untuk isbat nikah,

${ }_{10}$ Wawancara dengan bapak Asep selaku salah satu hakim yang terlibat dalam perumusan aturan pembatasan isbat nikah pada sidang keliling 22 April 2019.

11 Wawancara dengan bapak Asep selaku salah satu hakim yang terlibat dalam perumusan aturan pembatasan isbat nikah pada sidang keliling, 22 April 2019.

${ }_{12}$ Ad-Duraiswisy, Yusuf, 2010, Nikah Sirih, Mutah Dan Kontrak: Dalam Timbangan Al- Qur'an An Dan As-Sunnah. etakan Pertama Juni. Darul Haq. Jakarta.

Jurnal Al-Ahwal Al-Syakhsiyyah : Jurnal Hukum Keluarga dan Peradilan Islam 33 
fakta yang disampaikan oleh pak Asep sebagai hakim Pengadilan Agama Cianjur. "Lalu isbat ini juga bukan salah satu payung hukum bagi mereka yang tidak punya surat nikah tapi solusi yang telah terjadi jangan dibikin jadi, apalagi menjadi jalan pintas, diupayakan jangan sampai terjadi, semakin berkurang pemahaman kita, semakin faham beban ke pengadilan juga semakin berkurang menjadi tidak ada kasus isbat nikah." 13

Kelima, Usia pemohon yang mengajukan perkara isbat nikah ke Pengadilan Agama Cianjur itu relatif lansia hal tersebut sesuai dengan fakta yang ditemukan dari hasil wawancara, adapun hasil kutipan wawancara. "Kemudian dari keadaan usia prinsipal umumnya lebih tua dan lebih banyak, dari pada itu alasan nampaknya mereka berdasarkan ketidak tahuan (Wong Deso), kemudian dari alasan- alasan itu sidanng keliling kita yang aktif kesana, jadi mereka yang isbat nikah di desa itu orang tua- orang tua yang usia pernikahan nya di bawah 2010 ke bawah."14

\section{Proses Pelaksanaan Sidang Keliling Isbat Nikah dengan Batasan Waktu dalam Sidang Keliling di Pengadilan Agama Cianjur}

Pelaksanaan sidang keliling Terpadu ini yang dilaksanakan di Kantor Camat Cidaun. Selain pelaksanaan sidang keliling, pada hari itu juga diadakan sosialisasi tentang Perma No. 1 tahun 2015 tentang Pelayanan Terpadu Sidang Keliling Pengadilan Negri dan Pengadilan Agama/Mahkamah Syari'ah dalam rangka penerbitan Akte Perkawinan, Buku Nikah dan Akte Kelahiran yang disampaikan. Oleh Ketua Pengadilan Agama DR. H. Mahmud, HD. MH. ketua Pengadilan Agama berharap agar program tersebut berjalan dengan baik : “Kegiatan ini diharapkan dapat meningkatkan kesadaran hukum Masyarakat akan pentingnya kepemilikan akte resmi sebagai syarat pengakuan Negara atas peristiwa pernikahan yang harus dicatatkan di KUA Kecamatan dan Pencatatan Kelahiran anak pada Dinas Kependudukan Catatan Sipil. Selanjutnya Ketua Pengadilan Agama berharap semoga kegiatan sidang keliling terpadu ini dapat dilaksanakan berkelanjutan agar masyarakat yang belum mendapatkan pelayanan pada kesem- patan kali ini bisa mendapatkan pelayanan serupa pada kesempatan lain."15

Dengan adanya sosialisasi ini masyarakat yang pernikahannya tidak tercatat, apakah disebabkan faktor ekonomi, biaya, geografi atau lainnya, disisi lain begitu pentingnya Akte Nikah maupun Akte Kelahiran dengan rentetan akibat hukumnya seperti : Kewarisan, kewarganegaraan, jasa raharja, status anak dan lainya,

13 Wawancara dengan bapak Asep selaku salah satu hakim yang terlibat dalam perumusan aturan pembatasan isbat nikah pada sidang keliling, 22 April 2019.

14 Wawancara dengan bapak Asep selaku salah satu hakim yang terlibat dalam perumusan aturan pembatasan isbat nikah pada sidang keliling, 22 April 2019.

${ }^{15}$ Mahmud, Ketua Pengadilan Agama Cianjur, Wawancara, pada tanggal 22 April 2019

34 Jurnal Al-Ahwal Al-Syakhsiyyah : Jurnal Hukum Keluarga dan Peradilan Islam 
sementara setiap warga negara Republik Indonesia berhak mendapatkan pengakuan dan kepastian hukum, maka untuk menyelesaikan permasalahan tersebut Mahkamah Agung Republik Indonesia telah menerbitkan PERMA Nomor 1 tahun 2015 tentang "Pelayanan Terpadu Sidang Keliling Pengadilan Negeri (PN), Pengadilan Agama (PA)/Mahkamah Syari'ah dalam rangka penerbitan Akte Perkawinan, Buku Nikah dan Akte Kelahiran".

\section{Tinjauan Yuridis terhadap Pelaksanaan Sidang Keliling Perkara Isbat Nikah di Pengadilan Agama Cianjur.}

Pertama, Berdasarkan aturan tersebut ketua Pengadilan Agama Cianjur mengeluarkan kebijakan yang merujuk kepada perma no 1 tahun 2015, fakta tersebut di dapat dari hasil wawancara dengan bapak Asep sebagai salah satu hakim senior di Pengadilan Agama Cianjur, adapun kutipannya. "Merujuk kepada Perma no 1 Tahun 2015 tentang sidang terpadu, sidang terpadu itu melayani masyarakat mulai dari identitas diri, mereka yang tidak mempunyai surat nikah di berikan surat nikah, kemudian dari situ lahir kartu keluarga, akta kelahiran kamudian dari pada itu dipadukan, melahirkan buat anak-anak lahir akta kelahiran dan buat pasangan suami istri lahirlah akta nikah dilaksanakan di dalam satu pelayanan. Idealnya dalam persidangan itu tiga instansi itu hadir dalam persidangan diantaranya petugas dari Pengadilan Agama menisbatkan dan mengeluarkan isbat nikah, disdukcapil, dan dari Kantor Urusan Agama (KUA) mengeluarkan Akta Nikah semua instansi itu di padukan, itu yang dinamai sidang terpadu, itu dengan pelaksanaan."16

Kedua, Berdasarkan kewenangnan ketua Pengadilan Agama juga merujuk kepada fungsi ketua Pengadilan Agama Nomor 9 yaitu "Memperhatikan keluhankeluhan dari masyarakat dan menaggapinya bila dipandang perlu." Maka ketua Pengadilan Agama Cianjur mebuat kebijakan "Bagi pernikahan yang di lakukan di atas tahun 2010 sidang perkara Isbat Nikah dilaksanakan di kantor Pengadilan Agama Cianjur, adapun yang di bawah batasan pernikahan tahun 2010 sidang perkara Isbat Nikah di laksanakan di tempat sidang keliling." Adapun proses pembuatan aturannya sebagai berikut. "pembuatan aturan di pengadilan agama cianjur itu di buatkan langsung oleh ketua, jadi tiap pergantian ketua itu ada kebijakan, karena pembatasan itu memang penting untuk meminimalisir supaya tidak terus bertambah."17

\section{SIMPULAN}

Dari beberapa uraian diatas adalah merupakan hasil penelitian terhadap "Batasan

16 Wawancara dengan bapak Asep selaku salah satu hakim yang terlibat dalam perumusan aturan pembatasan isbat nikah pada sidang keliling, 22 April 2019.

17 Wawancara dengan bapak Asep selaku salah satu hakim yang terlibat dalam perumusan aturan pembatasan isbat nikah pada sidang keliling, 22 April 2019. 
Waktu Perkawinan dalam Perkara Isbat Nikah pada Sidang Keliling di Pengadilan Agama Cianjur" antara lain:

Latar belakang adanya batasan waktu perkawinan dalam perkara isbat nikah yang di selesaikan dalam sidang keliling di pengadilan Agama Cianjur dilatar belakangi oleh beberapa faktor. adapun faktor-faktor tersebut adalah sebagai berikut: 1 . banyaknya perkara isbat nikah pada tahun 2010 ke bawah; 2. usia pemohon; 3. kondisi fisik pemohon; 4. dasar hukum; 5. kewenangan ketua pengadilan agama; 6. budaya kawin sirri; dan 7. kesadaran masyarakat akan hukum.

Proses Pelaksanaan Sidang Keliling Isbat Nikah dengan Batasan Waktu dalam Sidang Keliling di Pengadilan Agama Cianjur tidak berbeda dengan proses pelaksanaan sidang keliling perkara isbat nikah. Adapun prosesnya adalah sebagai berikut: 1 . Pendaftaran perkara sidang keliling dan itsbat nikah; 2. Proses pelaksanaan sidang keliling dan itsbat nikah. (Tahapan-tahapan pelaksaan sidang keliling itsbat nikah di Pengadilan Agama Cianjur adalah: a. Tahap pemeriksaaan sidang keliling perkara Itsbat nikah; b. Tahap pembuktian sidang keliling perkara itsbat nikah ; c. Tahap kesimpulan; d. Tahap penetapan)

Penundaan sidang. Analisis yuridis terhadap pelaksanaan sidang keliling perkara itsbat nikah di pengadilan Agama Cianjur, tidak bertentangan kepada PERMA No 1 Tahun 2015 BAB IV Tentang Mekanisme Pelayanan Terpadu. Berdasarkan kewenangan ketua Pengadilan Agama juga merujuk kepada fungsi ketua Pengadilan Agama Nomor 9 yaitu "Memperhatikan keluhan-keluhan dari masyarakat dan menaggapinya bila dipandang perlu."

\section{DAFTAR PUSTAKA}

Ad-Duraiswisy, Yusuf, 2010, Nikah Sirih, Mutah Dan Kontrak: Dalam Timbangan AlQur'an An Dan As-Sunnah. cetakan Pertama Juni. Darul Haq. Jakarta.

Djamaan Nur, Fiqh munakahat, (Semarang:Toha Putra, 1993) hlm.1 Edi Suharto, Analisis Kebijakan Publik, Bandung: Alfabeta,2005, hal 7

Hasil Penelitian di Pengadilan Agama Cianjur, 22 April 2019

Hasil Wawancara dengan Hakim PA Cianjur Asep, S.Ag., M.H.tanggal 22 April 2019

Hasil Wawancara dengan Panitera Muda Hukum PA Cianjur Ayi Farihat Afiyati, M.H., tanggal 22 April 2019

Mahmud, Ketua Pengadilan Agama Cianjur, Wawancara, pada tanggal 22 April 2019.

Mukti Arto, Praktek Perkara Perdata Pada Pengadilan Agama, (Yogyakarta : Pustaka Pelajar, 1996, hlm. 41 
Fahmi Muwahid, Riyah Ramdhani Batasan Waktu Perkawinan dalam Perkara Isbat Nikah

Nazir.. Metode Penelitian, Ceatakan kedelapan, Bogor: Ghalia Indonesia. 2013. Hlm.43

Perma No. 1 Tahun 2014 Pedoman Pemberian Layanan Hukum Bagi Masyarakat Tidak Mampu di Pengadilan.

SK Ketua Muda MA RI Urusan Lingkungan Pengadilan Agama No. 01/SK/TUADAAG/I/2013 tentang Pedoman Sidang Keliling di Lingkungan Peradilan Agama, hal 3

Tim Penyusun Kamus, Kamus Besar Bahasa Indonesia, (Jakarta : Balai Pustaka, 1990), Cet. Ke-3, hlm. 339.

UU NO 1 Thn 1974 UU Perkawinan 
Volume I, Nomor 01, Maret 2020

38 Jurnal Al-Ahwal Al-Syakhsiyyah : Jurnal Hukum Keluarga dan Peradilan Islam 